\title{
Column \\ Over disciplinaire hokjes en bedrijfskunde
}

\author{
Jos Benders*
}

Ergens heb ik een doctoraalbul liggen waarop vermeld staat dat ik (in Tilburg) economie heb gestudeerd. Degenen die daarin verder zijn gegaan, zullen mij echter niet als econoom her-en erkennen. Mijn specialisatie was namelijk bedrijfseconomie (wat al suspect is), en mijn afstudeerrichting iets van organisatiekunde (dat is nog erger). Deze ziel doolde verder in wetenschapsland door met een promotieproject te beginnen. Dat begon als bedrijfseconoom, en werd formeel beëindigd als beleidswetenschapper (wat dat is, weet ik nog steeds niet). Dat was in Nijmegen, waar ik deel ging uitmaken van een club die iets van Bedrijfs- en bestuurskunde heette, maar al snel werd gesplitst in bedrijfsen bestuurskunde. Mijn thuishaven werd de vakgroep?, sectie?, afdeling? Bedrijfskunde, later herdoopt tot bedrijfswetenschappen (ik geloof niet dat ik in Nijmegen langer dan drie jaar een zelfde visitekaartje heb gehouden; het is er een continue herverbouw). Eind december 2006 belandde ik dan op een leerstoeltje bij het departement Organisatiewetenschappen van de Faculteit der Sociale Wetenschappen van de Universiteit van Tilburg. Kortom: nu ik deel heb uitgemaakt van allerlei verschillende disciplines bevind ik me klaarblijkelijk in een goede uitgangspositie om te voldoen aan het verzoek van TvA om een, uiteraard volstrekt subjectieve, column over bedrijfskunde te schrijven.

$\mathrm{Nu}$ heeft het lang geduurd voordat ik enige helderheid verkreeg in de disciplinaire chaos waarin ik me bevond en bevind. Ben ik nu een bedrijfskundige? Het antwoord op die vraag vereist een duidelijke afbakening van die discipline, zodat zij ten opzichte van andere disciplines kan worden geplaatst en vergelijkingen mogelijk zijn. Je zou verwachten die afbakening te vinden in het object van studie: bedrijven, of zoals Van Hoof in zijn slotbeschouwing stelt, organisaties. Het punt is echter dat de bedrijfskunde hier geen monopolie heeft: meerdere disciplines, met wat mij betreft de organisatiesociologie voorop, begeven zich op hetzelfde terrein. Het studieobject alleen is dus onvoldoende onderscheidend om de bedrijfskunde af te bakenen.

Ik heb ook nog wel een tijd in de veronderstelling gewerkt dat bedrijfskundigen (in de Nederlanden vallen bedrijfseconomen c.q. toegepast economen hier ook onder) vooral prescriptief werken, en ook actief meewerken aan het oplossen van bedrijfsproblemen. Deeldisciplines als 'operations management' en informatiemanagement zijn voorbeelden van gebieden waarvan veel beoefenaren geregeld op de werkvloer komen om praktijkgericht onderzoek te doen. Een discipline als organisatiesociologie zou dan descriptiefanalytisch werken: een bepaald fenomeen wordt onderzocht en in kaart gebracht, maar men gaat niet zo ver om organisaties mee te helpen met oplossingen. Maar ook op dit onderscheid is veel af te dingen. Ten eerste is inzicht in een fenomeen nodig om het gericht te kunnen oplossen, c.q. proberen aan een oplossing bij te dragen. Ten tweede zijn er ook veel descriptief ingestelde bedrijfskundigen, en prescriptief ingestelde organisatiesociologen. Empirisch onderzoek zou kunnen uitwijzen in hoeverre beide oriëntaties in de genoemde disciplines vertegenwoordigd zijn. Hier volstaat het te constateren dat er de nodige uitzonderingen zijn.

* Jos Benders is hoogleraar aan het departement Organisatiewetenschappen van de Universiteit van Tilburg. E-mailadres: Jos.Benders@uvt.nl. 
Dichter in de buurt van de empirische realiteit komt misschien de hypothese dat sociologen zich bewust zijn van de verschillende belanghebbende partijen in organisaties (of moet ik tegenwoordig 'stakeholders' zeggen?), terwijl bedrijfskundigen apolitiek zijn. Als bedrijfskundigen werken aan organisatieproblemen lijken ze zich zelden te bekommeren om wie de voordelen daarvan plukt. Voor veel sociologen, zeker die uit de hoek van de Labour Process-benadering, is dat onbegrijpelijk: daar leeft het marxisme nog, en wordt de empirie geïnterpreteerd vanuit het perspectief van de strijd tussen arbeid en kapitaal. Uiteraard dient men te kiezen voor de partij van de arbeider. Bedrijfskundigen gelden dan als helpers van de kapitalistische vijand. Zelf lijken de meeste bedrijfskundigen zich hierom niet bekommeren. Men dient de organisatie te helpen, en houdt zich niet bezig met de vraag wie dat dan ten goede komt. Men werkt voor 'het algemeen belang'. Vandaar mijn term 'apolitiek' om de maatschappelijke houding van de bedrijfskundigen te duiden. Opnieuw zijn er echter weer veel uitzonderingen. De opkomst van 'critical management studies' wijst op een grote en mogelijk nog groeiende groep bedrijfskundigen die met onderzoek proberen op te komen voor allerlei in hun ogen benadeelde groepen. Aan de andere kant blijken klassieke belangengroepenanalyses nog steeds een nuttig instrument uit de sociologie om managementvraagstukken op te lossen.

Misschien zit het enige steekhoudende onderscheidende kenmerk tussen bedrijfskundigen en andere disciplines in de instituties waarbinnen ze zich begeven. Centraal daarin staan de faculteiten, maar ook beroepsverenigingen met hun journals en conferenties en financieringsstromen zijn van belang. Hierbinnen zijn gevestigde belangen geconcentreerd, en kan het disciplinaire argument worden gebruikt voor in- en uitsluiting van individuen. Opvallend is dan dat er wel de nodige sociologen in bedrijfskundige faculteiten werken, maar nauwelijks bedrijfskundigen binnen de sociale faculteiten. De arbeidsmarkt voor academici speelt hier echter weer een belangrijke rol.

Mijn conclusie uit het bovenstaande is dat ik er ook niet helemaal uit kom. Met studieobject, prescriptieve-descriptieve oriëntatie, maatschappelijk-politieke oriëntatie en zeker instituties zijn beslist wel enkele lijnen te trekken, maar ze zijn allemaal permeabel. Voor mij is belangrijker te profiteren van een basisinzicht uit de structuratietheorie: structuren belemmeren en faciliteren gedrag, en gedrag bestendigt dan wel verzwakt structuren. De (bedrijfskundige?) implicatie is dat het verstandig is om je zo weinig mogelijk te laten remmen door structuren, en hun mogelijkheden om te faciliteren zo veel mogelijk benutten. Laat je niet remmen omdat een inzicht of publicatie of individu uit een andere hoek komt, maar vraag je af wat je eraan hebt voor het fenomeen dat je bestudeert. 